\title{
Preface to Lionel Johnson, 'Poetry and Patriotism', in Poetry and Ireland: Essays by W. B. Yeats and Lionel Johnson (1908)
}

The following essay was delivered as a lecture, ${ }^{1}$ and I have left out those unimportant opening words, which a lecturer finds necessary, that his audience may grow used to his voice and his appearance.

Lionel Johnson was small bu delicately made, and with great dignity of manner, and he spoke with so much music that what had been in another monotony, became nobility of style. His reading or speaking of poetry befitted his own particularly, that had from scholarship and from the loneliness and gravity of his mind an air of high lineage, but even poor verses were beautiful upon his lips. I think no man ever saw him angry or petulant, or till his infirmity had grown on him, ${ }^{2}$ shaken from his self possession, and it often seemed as if he played at life, as if it were an elaborate ritual that would soon be over. I am certain he had prevision of his end, and that he was himself that mystic and cavalier who sang:

Go from me: I am one of those, who fall.

What! hath no cold wind swept your heart at all,

In my sad company? before the end,

Go from me, dear my friend!

Yours are the victories of light: your feet

Rest from good toil, where rest is brave and sweet.

But after warfare in a mourning gloom,

$I$ rest in clouds of doom.

Have you not read so, looking in these eyes,

Is it the common light of the pure skies,

Lights up their shadowy depths? the end is set:

Though the end be not yet. 